\title{
Heat Transfer Measurement within Green Roof with Incinerated Municipal Solid Waste Aggregates
}

\author{
Mostafa Kazemi *(D), Luc Courard (D) and Julien Hubert \\ GeMMe Building Materials, Urban and Environmental Engineering Division (UEE), University of Liege, \\ 4000 Liège, Belgium; luc.courard@uliege.be (L.C.); julien.hubert@uliege.be (J.H.) \\ * Correspondence: mostafa.kazemi@uliege.be
}

Citation: Kazemi, M.; Courard, L.; Hubert, J. Heat Transfer Measurement within Green Roof with Incinerated Municipal Solid Waste Aggregates. Sustainability 2021, 13, 7115. https:// doi.org/10.3390/su13137115

Academic Editors: Domenico Mazzeo, Danièle Waldmann-Diederich and Laddu Bhagya Jayasinghe

Received: 11 May 2021

Accepted: 19 June 2021

Published: 24 June 2021

Publisher's Note: MDPI stays neutral with regard to jurisdictional claims in published maps and institutional affiliations.

Copyright: (c) 2021 by the authors. Licensee MDPI, Basel, Switzerland. This article is an open access article distributed under the terms and conditions of the Creative Commons Attribution (CC BY) license (https:/ / creativecommons.org/licenses/by/ $4.0 /)$.

\begin{abstract}
A green roof is composed of a substrate and drainage layers which are fixed on insulation material and roof structure. The global heat resistance (Rc) within a green roof is affected by the humidity content of the substrate layer in which the coarse recycled materials can be used. Moreover, the utilization of recycled coarse aggregates such as incinerated municipal solid waste aggregate (IMSWA) for the drainage layer would be a promising solution, increasing the recycling of secondary resources and saving natural resources. Therefore, this paper aims to investigate the heat transfer across green roof systems with a drainage layer of IMSWA and a substrate layer including recycled tiles and bricks in wet and dry states according to ISO-conversion method. Based on the results, water easily flows through the IMSWAs with a size of $7 \mathrm{~mm}$. Meanwhile, the Rc-value of the green roof system with the dry substrate $\left(1.26 \mathrm{~m}^{2} \mathrm{~K} / \mathrm{W}\right)$ was 1.7 times more than that of the green roof system with the unsaturated substrate $\left(0.735 \mathrm{~m}^{2} \mathrm{~K} / \mathrm{W}\right)$. This means that the presence of air-spaces in the dry substrate provided more heat resistance, positively contributing to heat transfer decrease, which is also dependent on the drainage effect of IMSWA. In addition, the Rc-value of the dry substrate layer was about twice that of IMSWA as the drainage layer. No significant difference was observed between the Rc-values of the unsaturated substrate layer and the IMSWA layer.
\end{abstract}

Keywords: heat transfer; incinerated municipal solid waste aggregate; water content; green roof

\section{Introduction}

Over the past few decades, the rapid increase in urban areas has exerted pressure on the environment owing to the high consumption of natural resources in the construction sector and low energy performance of building envelope components such as walls and roofs. For instance, $60-80 \%$ of global energy consumption has been derived from urban areas, even though they occupy only $3 \%$ of the Earth's land [1-5]. Since the greatest amount of urban spaces has been covered by roofing systems [6], the use of green roofs as one of the building envelope components has been proposed, and it has been frequently installed in rooftops to broaden the green infrastructure with high energy efficiency in the construction process [7-10]. The green roofs can promote the heating and cooling energy performance of dwelling houses in an urban area. The decrease in the urban heat island influence is another advantage of green roof systems. Additionally, rainwater runoff can be reduced and delayed when a green roof is used for the rooftops [9,11-14].

The green roof classification is dependent on its thickness and its weight. Among nature-based solutions for roofing systems, the extensive green roof has the shallowest depth and the lightest weight and it includes vegetation, substrate, filter, drainage and insulation layers, from top to the bottom [14,15]. The physical properties of materials used for the substrate and drainage layers can noticeably influence the permeability and thermal performance of roofing systems [16]. Furthermore, high porosity of substrate layer can contribute to promoting the insulation performance of a green roof [17]. Moreover, the green roof's heat resistance is affected by the moisture content of substrate layer in 
which the media mixtures can be used in wet and dry states $[8,18]$. Concerning this, a study by Kotsiris et al. [19] on green roof systems showed that there was a linear relation between the substrate's thermal conductivity and its moisture content, even though this linear assumption seemed to not be realistic as reported by other researchers [20-23]. The moisture content effect on the green roof performance during dry periods was evaluated by Berretta et al. [24]. The vertical profile of the moisture content was highly dependent on the substrate's characteristics. Moreover, the diurnal temperature fluctuation led to a daily reduction in moisture content owing to evapotranspiration during the warmer hours of the day. A study by He et al. [25] on green roof thermal behavior showed that increasing the evapotranspiration phenomenon increased with the presence of water content in the substrate layer during the summer period, contributing to promoting the green roof's thermal performance due to increasing the evaporated water. Pianella et al. [26] revealed that the media mixtures used for substrate layer influenced the green roof's thermal conductivity. In addition, increasing the media mixtures' moisture content led to increasing the substrate layer's thermal conductivity; hence, the green roof with a dry substrate had the lowest thermal conductivity. Fabisni et al. [27] showed that the water content noticeably affected the substrate and drainage layers' thermal properties, in which the thermal conductivity of substrate increased by triple during the raining periods. Another study by Almeida et al. [28] on green roof's thermal behavior demonstrated that the presence of a substrate layer increased the thermal insulation of green roof systems, while its insulation capacity in wet state was not as much as that in dry state. Recently, He et al. [29] showed that the green roof's cooling effect increased by increasing the substrate' water content. Moreover, the cooling and heating loads of buildings decreased once the green roof was used for the rooftops.

The drainage layer of green roof systems is responsible for draining the water from overlying layers of green roof systems. Regarding this, the use of coarse granular aggregates for the drainage layer has been proposed by researchers [30]. A type of volcanic porous materials was used by Palla et al. [31] for the drainage layer of roofing systems. As per the experimental observation, the extra water easily passed through the vertical profile of roofing systems once the volcanic porous material was used as the drainage layer. Additionally, some amounts of water molecules were trapped in the empty pores of volcanic materials. The use of natural materials for the drainage layer of green roof systems can impose a heavy impact on the environment. By using recycled materials for the drainage layer, the burden on both the cost of construction process and the environment can be reduced by saving natural resources [32-38]. Concerning this, the thermal performance effect of rubber crumbs and pozzolana as a drainage layer on roofing systems was assessed by Coma et al. [39,40]. As per the results, more insulation capacity was observed for green roofs with rubber crumbs rather than those with volcanic gravel during the summer period. For the winter period, they suggested to increase the thickness of green roof layers to promote the roofing systems' insulation capacity. Concerning this, Kazemi et al. $[8,14]$ showed that due to higher internal temperature during the winter period, the presence of water content in the substrate and drainage layers led to absorption of the internal ceiling temperature, and subsequently caused them to consume more heating loads and energy in cold periods.

Based on the above, although the green roof system has a separate insulation layer, the materials used for the substrate and drainage layers can affect the insulation performance and the heat resistance of rooftops. Moreover, it is required to assess the thermal resistance of green roof systems without a vegetation layer, because, in some cases, the vegetation coverage of rooftops is scarce, particularly during the winter season and hot summer periods [39]. In such conditions, the substrate and drainage layers can play a fundamental role in providing heat resistance for rooftops. On the other hand, since the coarse recycled materials have an adequate moisture retention capacity as well as a suitable water passing ability [32,41-43], they have a comparative advantage in providing enough thermal performance for the substrate and drainage layers of green roof systems $[8,14]$, while there 
are few studies for selecting appropriate coarse recycled materials and assessing their thermal performance for rooftops [14]. Moreover, the heat resistance of a substrate with coarse recycled materials in wet and dry states is required to be evaluated and compared to each other once the media mixtures' moisture content can affect the roofing systems ${ }^{\prime}$ thermal resistance $[8,18]$. Therefore, in this study, the heat resistance of green roof systems with a drainage layer of incinerated municipal solid waste aggregate (IMSWA) and a substrate layer with recycled tiles and bricks in wet and dry states was assessed following ISO 9869-1 [44]. After that, the effect of media mixtures' moisture content on thermal performance of green roof was investigated. Moreover, the drainage and substrate layers were separately exposed to the temperature to measure their heat resistance.

\section{Experimental Program}

\subsection{Methodology}

The extensive green roof includes vegetation, substrate, filter, drainage and insulation layers, from the top to the bottom, as shown in Figure 1 [14,15]. Since the drainage and substrate layers could contain the coarse recycled materials, this study only focused on the thermal resistance of these two layers. The drainage layer included IMSWA, which was available in the market. The IMSWA was composed of the crushed ceramic, crushed aggregate, inert waste, crushed brick, and crushed glass. On the other hand, the commercial soil media with recycled tiles and bricks in dry and wet states was used for the substrate layer. The dry state could be representative of the substrate layer in a Mediterranean area with a summer non-rainy weather condition [45]. Therefore, two green roof systems were named S15-IMSWA5_Dry and S15-IMSWA5_Wet and they were considered in dry and wet states as presented in Table 1. As reported by other researchers [46], the green roof with 15-cm substrate can provide an adequate depth for growing different types of plants. Moreover, the drainage layer of granular materials with the thickness about $5 \mathrm{~cm}$ can provide a suitable condition for the dewatering of the green roof $[39,40]$. Therefore, the total thickness of green roof systems was $20 \mathrm{~cm}$ with the substrate and drainage layers' thicknesses at $15 \mathrm{~cm}$ and $5 \mathrm{~cm}$, respectively.

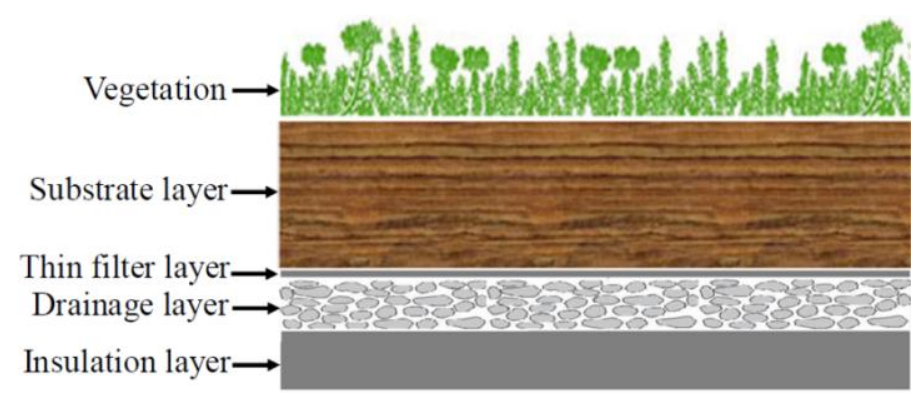

Figure 1. A cross-sectional view of green roof layers.

Table 1. Green roofs' geometrical configurations.

\begin{tabular}{cccc}
\hline \multirow{2}{*}{ No. } & \multirow{2}{*}{ Specimens ID } & \multicolumn{2}{c}{ Thickness $(\mathbf{c m})$} \\
\cline { 3 - 4 } & & Drainage Layer & Substrate \\
\hline 1 & S a $^{\text {15-IMSWA b 5_Dry }}$ & 5 & 15 \\
2 & S15-IMSWA5_Wet & 5 & 15 \\
3 & IMSWA & 5 & - \\
4 & S15_Dry & - & 15 \\
5 & S15_Wet & - & 15 \\
\hline
\end{tabular}

${ }^{a}$ Substrate. ${ }^{\mathrm{b}}$ Incinerated municipal solid waste aggregate.

As shown in Figure 2, a $40 \times 40 \times 20 \mathrm{~cm}$ experimental mold was used for testing the thermal resistance of green roof systems. It is noteworthy that a thin filter layer was used between the substrate and drainage layers to prevent them from mixing with each 
other (Figure 2). In the next step, the 15-cm substrate layers in dry and wet states (S15_Dry and S15_Wet) were separately put in a $40 \times 40 \times 15 \mathrm{~cm}$ experimental mold to measure their thermal resistance. After that, to assess the thermal resistance of IMSWA layer as the drainage layer with a thickness of $5 \mathrm{~cm}$, a $40 \times 40 \times 5 \mathrm{~cm}$ experimental mold was used. Moreover, a water transmissivity test was carried out to assess the water passing ability of IMSWA with a specific size. The geometrical configuration of specimens is presented in Table 1. To expose the top and the bottom of the specimens to the low and high temperatures, they were separately placed between the cold and hot plates of the thermal device. After that, the specimens were compressed between the aforementioned plates to measure their thermal conductivity. It is noteworthy that, in this study, it was assumed that the use of substrate in wet and dry conditions can affect the thermal resistance of the system, once the green roof layers contained coarse recycled materials. The temperature values were recorded in the center of the specimens and the surrounding area of the experimental molds were insulated using the polyurethane foam to provide adequate boundary conditions for the system. Following this, the Rc-values for different specimens were obtained using the Average Method of ISO 9869-1 [44] to carry out the one-dimensional thermal analysis through the depth of drainage layer and substrate in wet and dry conditions. Therefore, the heat resistance of green roof layers with the presence of water content and air-voids was measured and analyzed.

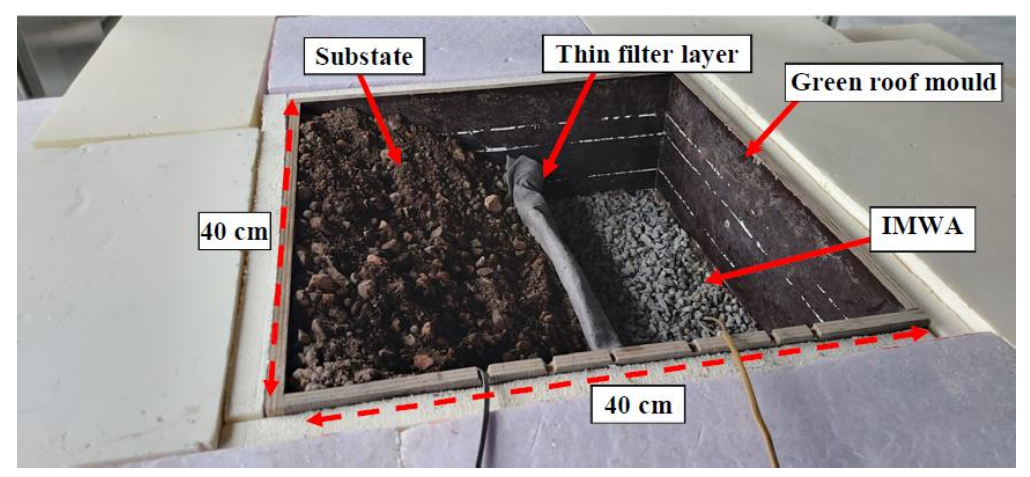

Figure 2. Substrate and the incinerated municipal solid waste aggregate layers in green roof mold.

The thermal device had a sensor in the hot plate to automatically measure the thermal conductivity of the specimens. Concerning this, the device measured the difference between the temperature at the top and bottom surfaces of specimen, which indeed was the difference between the hot and cold plates $(\Delta \mathrm{T})$ as presented in Equation (1):

$$
\Delta \mathrm{T}=\mathrm{T}_{\mathrm{h}}-\mathrm{T}_{\mathrm{c}}
$$

where $T_{c}$ and $T_{h}$ refer to the temperatures of cold and hot plates, respectively $(K)$.

Equation (2) was used for calculating the heat flow rate (q) with the unit of $\mathrm{W} / \mathrm{m}^{2}$ as suggested by the Fourier's law:

$$
\mathrm{q}=\lambda \cdot \frac{\Delta \mathrm{T}}{l}
$$

where $l$ is the thickness of green roof layers (m).

To evaluate the heat resistance of specimens, the R-value $\left(\mathrm{m}^{2} \mathrm{~K} / \mathrm{W}\right)$ was obtained using Equation (3), which was recommended by the Average Method of ISO 9869-1 [44]:

$$
\mathrm{R}_{\mathrm{c}}=\frac{\sum_{t=0}^{m} \Delta \mathrm{T}^{t}}{\sum_{t=0}^{m} \mathrm{q}^{t}}
$$

where $m$ is the minimum required measurement period $(\mathrm{h})$, and $t$ is the time interval. 


\subsection{Materials Properties}

Due to the effect of materials characteristics on the heat resistance of green roof systems $[8,18,47]$, the properties of substrate with coarse recycled materials and IMSWA were obtained as presented in Table 1 . The bulk density of substrate in wet and dry states was equal to $1000.95 \mathrm{~kg} / \mathrm{m}^{3}$ and $944.1 \mathrm{~kg} / \mathrm{m}^{3}$, respectively. The corresponding value for the IMSWA was $1147.26 \mathrm{~kg} / \mathrm{m}^{3}$. The specific heat capacity of substrate with coarse recycled materials and IMSWA was obtained by means of the Calorimetric method according to ASTM D4611-16 [48]. The substrate sample was taken directly from the experimental green roof mold and its water content in wet state was $87.35 \mathrm{~kg} / \mathrm{m}^{3}$. The corresponding value for IMSWA was $8.19 \mathrm{~kg} / \mathrm{m}^{3}$. These values were obtained by means of the gravimetric analysis following NF ISO 16586 [49]. In this analysis, the materials should be completely dried by keeping them inside of the oven at $105^{\circ} \mathrm{C}$ for $48 \mathrm{~h}$. To obtain the water holding capacity of materials, their free water content was measured using the gravimetric analysis. This parameter is attributed to the capillary action of materials, keeping the water content within their pores at $100 \%$ relative humidity. Indeed, the free water content value is lower than the maximum water content owing to the trapped air in materials' pores [35,50]. Concerning this, a method proposed by researchers $[51,52]$ was used to obtain the free water content value for IMSWA and substrate. The water absorption coefficient value was obtained based on EN 1925 [53] and it was equal to $0.067 \mathrm{~kg} / \mathrm{m}^{2} \mathrm{~s}^{0.5}$ and $0.22 \mathrm{~kg} / \mathrm{m}^{2} \mathrm{~s}^{0.5}$ for the IMSWA and substrate, respectively.

\section{Results and Discussion}

\subsection{Water Transmissivity (IMSWA Layer)}

The drainage layer of green roofs should be made using coarse aggregates to easily pass the water through the roofing systems [30,54]. As per EN 12620 [55], the minimum coarse aggregate size is $5 \mathrm{~mm}$. Moreover, the thinness of the IMSWA layer $(5 \mathrm{~cm})$ caused us to avoid using a big size for the drainage layer. Therefore, IMSWA with a size of $7 \mathrm{~mm}$ was considered for the drainage layer and its water passing ability was assessed using the water transmissivity test.

To assess the horizontal water passing ability of the IMSWA layer, the transmissivity test apparatus was used and carried out according to ASTM D4716 [56]. A cross-sectional view of the transmissivity test is shown in Figure 3, in which $\Delta \mathrm{h}$ was the difference in total head across the IMSWA layer. The load equivalent to the weight of substrate was used to apply to the top of IMSWA layer. Additionally, to prevent the water coming up from the sides of the load cell, a foam was used at its bottom. After following a high amount of water using the hose-pipe, the water horizontally passed through the IMSWA layer in less than one second, then the water surface was observed to have the same level at the two sides of the U-shape box apparatus, resulting in zero value for $\Delta \mathrm{h}$ parameter. Consequently, the drainage layer of IMSWA with a size of $7 \mathrm{~mm}$ was able to horizontally pass a high amount of water for the green roof systems, contributing to buffering the storm water runoff.

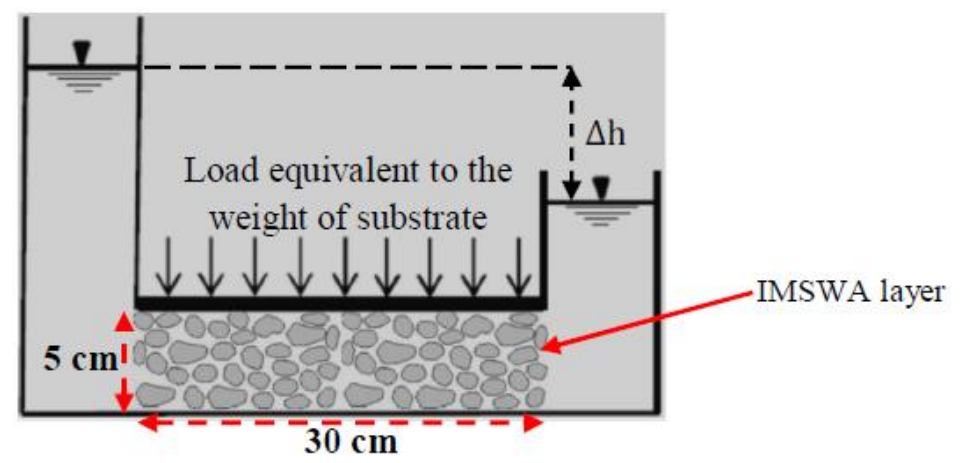

Figure 3. Schematic representation of water transmissivity test. 


\subsection{Temperature Distribution}

According to the experimental process, the applied temperature to the top of green roof specimens $\left(15^{\circ} \mathrm{C}\right)$ was lower than that to the bottom of green roof specimens $\left(26^{\circ} \mathrm{C}\right)$; hence, the temperature applied by the thermal device to the green roof specimens was representative of a cold period. Therefore, the effect of the dry and wet states of the substrate layer on the temperature distribution across the green roof systems (S15-IMSWA5_Wet and S15-IMSWA5_Dry) was assessed as shown in Figure 4.

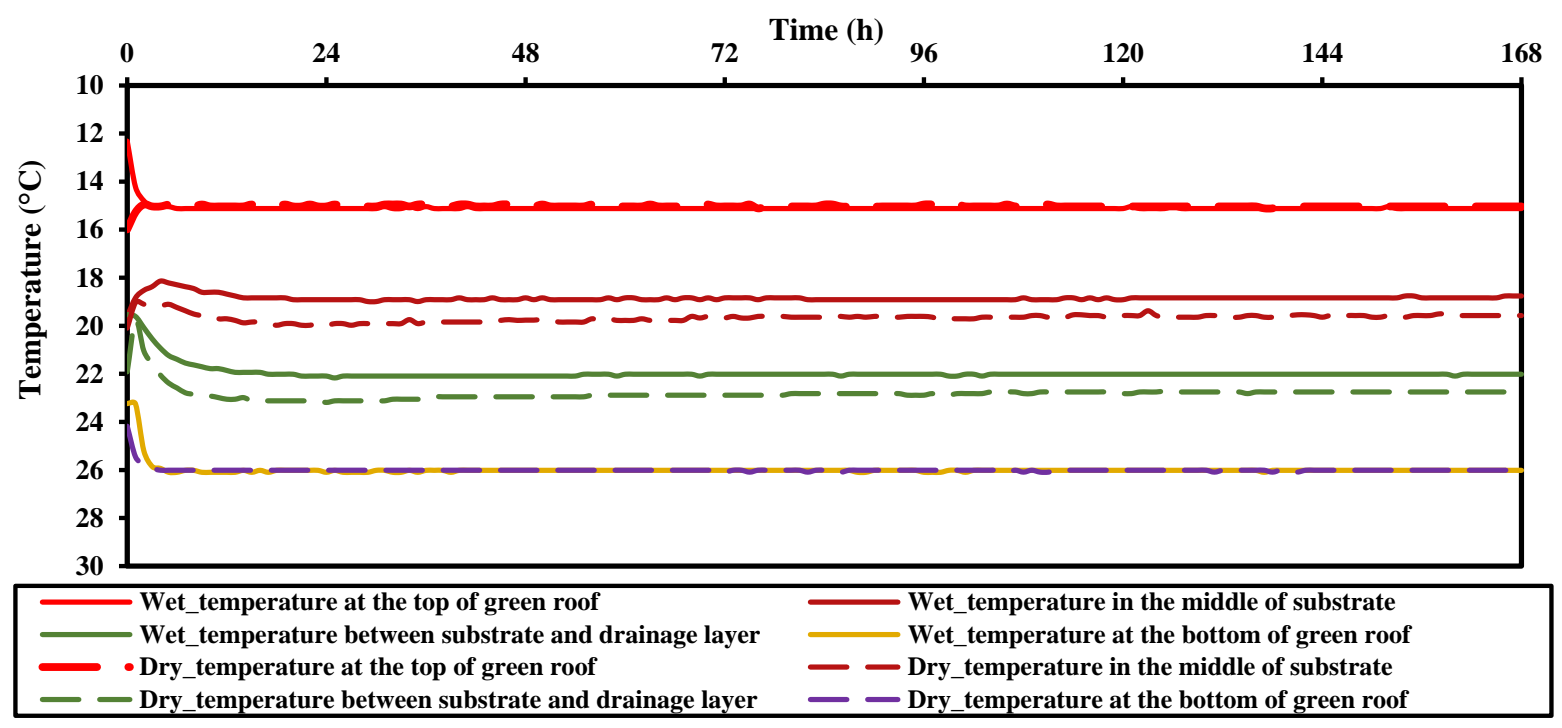

Figure 4. Temperature variation through the depth of green roof specimens with dry and unsaturated substrate.

According to the results, the average temperatures between the substrate and drainage layers for S15-IMSWA5_Dry and S15-IMSWA5_Wet specimens were $22.81^{\circ} \mathrm{C}$ and $22.02{ }^{\circ} \mathrm{C}$, respectively. The corresponding temperatures in the middle of substrate were $19.64^{\circ} \mathrm{C}$ and $18.87^{\circ} \mathrm{C}$, respectively. Therefore, the temperature through the depth of green roof specimen with the dry substrate was about $4 \%$ more than that with the unsaturated substrate, demonstrating that the former was slightly less affected by the cold plate at the top of the specimens $\left(15^{\circ} \mathrm{C}\right)$. It can be said that the water content in the unsaturated substrate caused it to absorb more cold temperature, resulting in a decrease of the thermal resistance of green roof systems and subsequently increasing the energy consumption [8,12,57]. Moreover, the thermal device' conditions were representative of a cold period; hence, the evapotranspiration phenomenon could not effectively occur as a consequence of the moisture content evaporation transferred from the substrate into the air. Similar results were also reported by Poë et al. [58], particularly for the winter period. Parallel to this, the heating conditions should be provided more for the inside of the buildings, once the substrate was in wet state.

\subsection{Thermal Resistance}

Figures 5 and 6 show the thermal conductivity and Rc-value of specimens following an extension to the average method of ISO 9869-1 [44]. The difference between the temperature of the hot and cold plates for all specimens was assumed to be more than $7{ }^{\circ} \mathrm{C}$ as it is recommended to be at least $5-10{ }^{\circ} \mathrm{C}$ for the Average Method $[44,59,60]$. The thermal properties of green roof systems and their layers are presented in Table 2. For all specimens, the convergence duration was assumed to be longer than $72 \mathrm{~h}$ according to ISO 9869-1 [44]. 


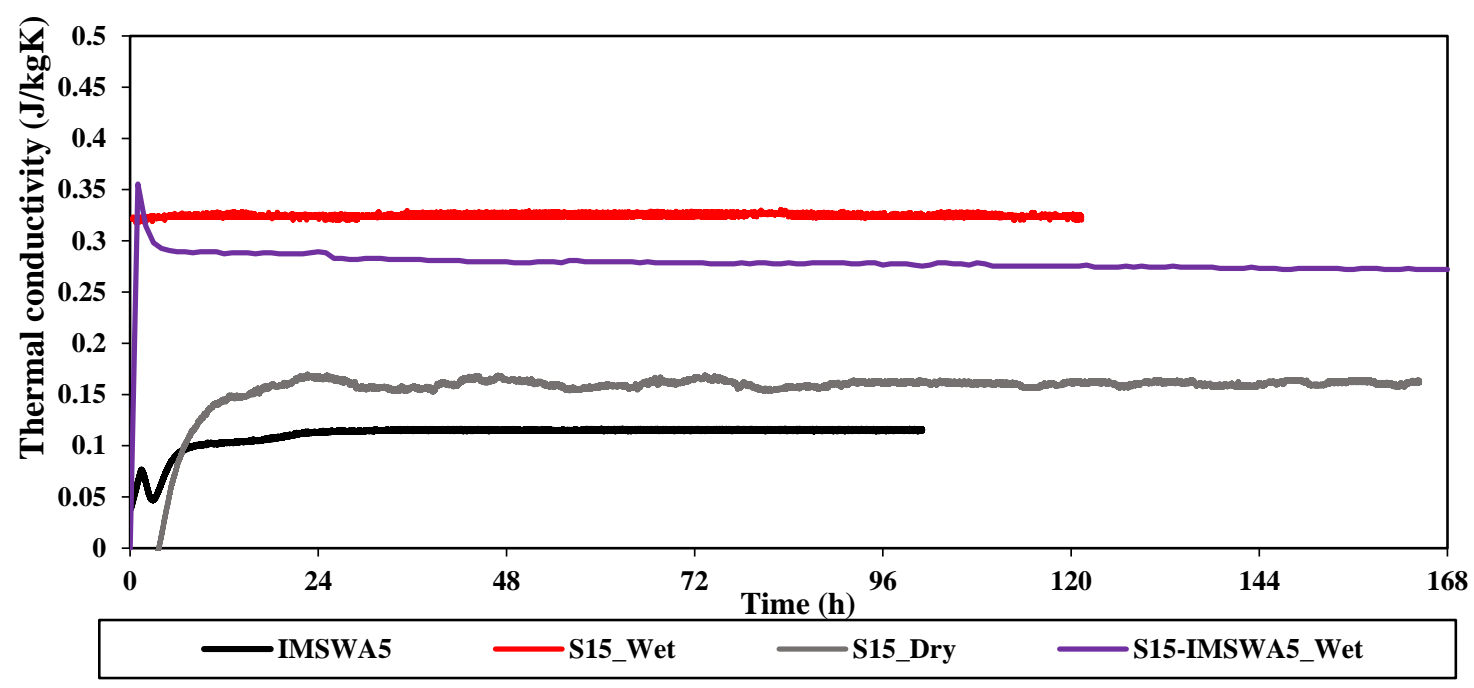

Figure 5. Green roof layers' thermal conductivity.

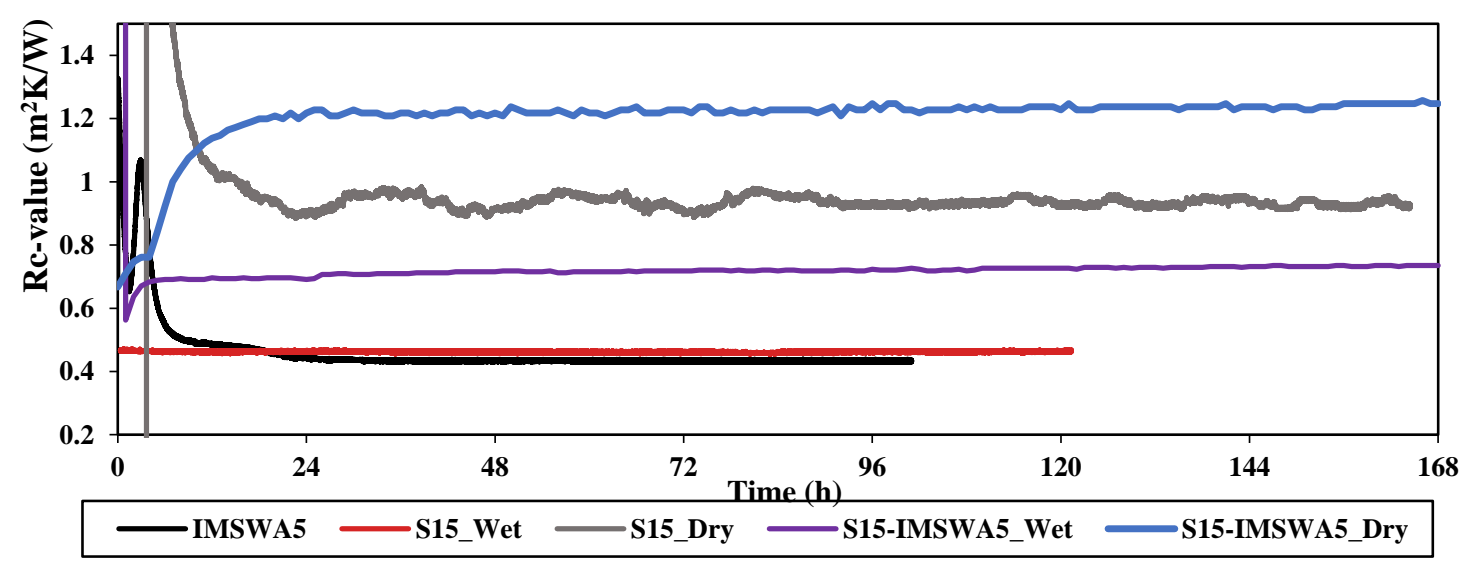

Figure 6. Green roof layers' Rc-value curves.

Table 2. Green roof layers' properties.

\begin{tabular}{lcc}
\hline Materials & $\begin{array}{c}\text { Substrate with Coarse } \\
\text { Recycled Materials }\end{array}$ & IMSWA \\
\hline Porosity & 0.4863 & 0.4726 \\
Specific heat capacity, Dry $(\mathrm{J} / \mathrm{kg} \cdot \mathrm{K})$ & 810 & 750 \\
Thermal conductivity, Dry, $\lambda(\mathrm{W} / \mathrm{m} \cdot \mathrm{K})$ & 0.17 & 0.115 \\
Water content $\left(\mathrm{kg} / \mathrm{m}^{3}\right)$ & 87.35 & 8.19 \\
Free water content $\left(\mathrm{kg} / \mathrm{m}^{3}\right)$ & 285.71 & 101.2 \\
Water absorption coefficient, $\mathrm{A}_{1}\left(\mathrm{~kg} / \mathrm{m}^{2} \mathrm{~s}^{0.5}\right)$ & 0.22 & 0.067 \\
\hline
\end{tabular}

As per the ISO-conversion method, the Rc-value at the end of the data set should not deviate more than $\pm 5 \%$ from the respective value obtained $24 \mathrm{~h}$ before. According to the results obtained for all specimens (Table 3), there was a difference less than $1 \%$ between the results at the end and $24 \mathrm{~h}$ before the end of the data set, meeting the ISO-conversion method's requirement. 
Table 3. Green roof layers' thermal properties.

\begin{tabular}{|c|c|c|c|c|c|c|}
\hline \multicolumn{2}{|c|}{ Specimens ID } & IMSWA5 & S15_Wet & S15_Dry & $\begin{array}{c}\text { S15- } \\
\text { IMSWA5_Wet }\end{array}$ & $\begin{array}{c}\text { S15- } \\
\text { IMSWA5_Dry }\end{array}$ \\
\hline \multicolumn{2}{|c|}{ Test duration $(\mathrm{h})$} & 101 & 122 & 165 & 168 & 168 \\
\hline \multicolumn{2}{|c|}{ Convergence duration (h) } & 76 & 73 & 75 & 120 & 120 \\
\hline \multicolumn{2}{|c|}{ Thermal conductivity $(\mathrm{W} / \mathrm{m} \cdot \mathrm{K})$} & 0.115 & 0.32 & 0.16 & 0.27 & 0.16 \\
\hline \multirow{5}{*}{ Rc-value $\left(\mathrm{m}^{2} \mathrm{~K} / \mathrm{W}\right)$} & $24 \mathrm{~h}$ before the end of data set & 0.432 & 0.463 & 0.94 & 0.732 & 1.25 \\
\hline & End of data set & 0.43 & 0.462 & 0.93 & 0.735 & 1.26 \\
\hline & $\begin{array}{l}\text { The first } 67 \% \text { of data during } \\
\text { the convergence period }\end{array}$ & 0.43 & 0.461 & 0.93 & 0.728 & 1.26 \\
\hline & $\begin{array}{l}\text { The last } 67 \% \text { of data during } \\
\text { the convergence period }\end{array}$ & 0.43 & 0.462 & 0.94 & 0.726 & 1.25 \\
\hline & $\begin{array}{l}\text { Average value during the } \\
\text { convergence period }\end{array}$ & 0.43 & 0.46 & 0.94 & 0.735 & 1.26 \\
\hline
\end{tabular}

Based on another criteria of ISO 9869-1 [44], the Rc-value when applying the method to the first $67 \%$ of data should not deviate by more than $\pm 5 \%$ from the respective value when analyzing the last $67 \%$ of the data. As per the results of all specimens (Table 3), $2.4 \%$ difference was mostly obtained between the results at the first and the last $67 \%$ of the convergence duration, which was less than $5 \%$ as recommended by ISO 9869-1 [44].

\subsection{Green Roof Layers' Heat Resistance}

To evaluate the heat transfer through the depth of materials, their thermal conductivity and Rc-value should be measured and calculated [26,61]. Table 2 shows the thermal properties of specimens following ISO 9869-1 [44]. According to the results, the Rc-value of the dry substrate, S15_Dry, $\left(0.94 \mathrm{~m}^{2} \mathrm{~K} / \mathrm{W}\right)$ was about twice that of the unsaturated substrate, S15_Wet, $\left(0.46 \mathrm{~m}^{2} \mathrm{~K} / \mathrm{W}\right)$, while the reverse was observed for the thermal conductivity value. Similar to this, a study by Pianella et al. [26] showed that the lowest thermal conductivity was obtained for the substrate once it was in dry state. It can be said that the thermal resistance of the trapped air is more than that of water content $[62,63]$. Considering this, the air-spaces among soil particles were more in the dry substrate than the unsaturated substrate; hence, the presence of air-spaces in the dry substrate provided more thermal resistance than the presence of water content in the unsaturated substrate.

As presented in Table 2, the Rc-value of the dry substrate layer, S15_Dry, $\left(0.94 \mathrm{~m}^{2} \mathrm{~K} / \mathrm{W}\right)$ was about twice that of IMSWA5 as the drainage layer $\left(0.43 \mathrm{~m}^{2} \mathrm{~K} / \mathrm{W}\right)$, while the thickness of the former was three times that of the latter. It seems that the air-spaces among IMSWAs effectively participated in increasing the drainage layer's thermal resistance. In addition, assuming the same thickness for IMSWA and dry substrate layers, the air-spaces among IMSWAs were found to be more than those among dry substrate's particles. In fact, the heat could not flow more easily across air-spaces as much as solid particles. Therefore, when the particles were tighter and compressed more, the contact points among particles increased, leading to facilitating the conduction heat transfer through substrate layers, similar to what other researchers revealed [26,64-67]. On the other hand, there was no significant difference between the Rc-value of the unsaturated substrate layer (S15_Wet) and IMSWA5, while the thickness of the former was three times that of the latter. It can be said that the air-spaces in IMSWA5 were more than those in the unsaturated substrate layer, and the presence of the water content in the latter provided the same heat resistance as the drainage layer of IMSWA5, while the thickness of the substrate layer was three times that of the drainage layer.

The effect of the unsaturated and dry substrate layer on the thermal resistance of green roof systems (S15-IMSWA5_Wet and S15-IMSWA5_Dry) was assessed. As presented in Table 2, the Rc-value of green roof system with dry substrate $\left(1.26 \mathrm{~m}^{2} \mathrm{~K} / \mathrm{W}\right)$ was 1.7 times more than that of the green roof system with the unsaturated substrate $\left(0.735 \mathrm{~m}^{2} \mathrm{~K} / \mathrm{W}\right)$, while the reverse was obtained for the thermal conductivity. In brief, an increase in thermal resistance of green roof systems can be a consequence of the increase of air-spaces among 
dry soil particles, outperforming the water content in the unsaturated soil particles. That is why the insulation performance of green roof systems was found to be adequate during the summer (warm) period, while, in some cases, the thermal resistance of roofing systems with the unsaturated substrate was less favorable during the winter (cold) period as reported by other researchers $[8,12,40,68]$.

\section{Conclusions}

The heat transfer capacity of green roof systems with IMSWA drainage layer and substrate layer including recycled tiles and bricks in wet and dry states was assessed following ISO-conversion method. As per the results and discussion, the major conclusions can be extracted as follows:

- This study contributes to the body of knowledge related to green roof and the results demonstrate to what extent the use of substrate in wet and dry conditions affect the thermal resistance of the system, once the green roof layers contain coarse recycled materials.

- Transmissivity through 5-cm IMSWA drainage layer is very high. Therefore, IMSWAs with a size of $7 \mathrm{~mm}$ had adequate capacity to horizontally pass a high amount of water for a green roof system.

- Temperature across the depth of green roof specimen with dry substrate (S15-IMSWA5_Dry) was about $4 \%$ higher than that with unsaturated substrate (S15-IMSWA5_Wet). The presence of moisture caused the substrate layer to be affected more by the outside cold temperature, resulting in an increase in energy consumption.

- According to the heat transfer measurement during the convergence duration (longer than $72 \mathrm{~h}$ ), a difference of less than $1 \%$ between the Rc-values of specimens at the end and $24 \mathrm{~h}$ before the end of the data set was observed. Moreover, $2.4 \%$ difference was noticed between the Rc-values of specimens at the first and the last $67 \%$ of the convergence duration. Therefore, the aforementioned differences were less than $5 \%$, meeting the ISO-conversion method's requirements.

- The Rc-value of the dry substrate including air-spaces was about twice that of the unsaturated substrate including water content. Therefore, the presence of air-spaces in the dry substrate provided more heat resistance than in the case of water in the unsaturated substrate.

- As per the results, the Rc-value of the dry substrate layer was about twice that of IMSWA5 as the drainage layer. Moreover, no significant difference was observed between the Rc-value of the unsaturated substrate layer and IMSWA5, while the thickness of the former was three times that of the latter. Therefore, the presence of air-spaces among IMSWAs played a key role in promoting the thermal resistance of drainage layer.

- The Rc-value of green roof system with dry substrate $\left(1.26 \mathrm{~m}^{2} \mathrm{~K} / \mathrm{W}\right)$ was 1.7 times higher than that of the green roof system with unsaturated substrate $\left(0.735 \mathrm{~m}^{2} \mathrm{~K} / \mathrm{W}\right)$, while the reverse was obtained for the thermal conductivity. Therefore, the air-spaces among dry soil particles outperformed the water content in media mixtures to promote the heat resistance of rooftops.

The use of IMSWAs for the drainage layer in green roof systems represents an interesting solution for helping water evacuation and, additionally, dry the substrate layer. This implies a high thermal resistance and better insulating properties of the green roof system. Moreover, according to the experimental works in lab-scale, the 5-cm drainage layer of IMSWA can be considered as a potential material for the green roof system and further researches are required for assessing its applicability for real building structures. On the other hand, since the vegetation coverage at rooftops is scarce in some cases, this study only focused on the thermal resistance of the drainage and substrate layers without plant coverage. Therefore, the main limitation of this study was that the effect of a vegetation layer on the green roof system' thermal performance could not be assessed. 
Author Contributions: M.K.: data curation, modeling, investigation, methodology, writing original draft; L.C.: funding acquisition, supervision, writing review and editing; J.H.: writing review and editing. All authors have read and agreed to the published version of the manuscript.

Funding: This research was funded through the University of Liège (ULiège) and the ARC grant for Concerted Research Actions, financed by the French Community of Belgium, Wallonia-Brussels Federation (CityRoof project: Analogous green roofs for urban ecosystem services (2020-2023)).

Institutional Review Board Statement: Not applicable.

Informed Consent Statement: Not applicable.

Data Availability Statement: Not applicable.

Conflicts of Interest: The authors declare no conflict of interest.

\section{References}

1. Manso, M.; Teotónio, I.; Silva, C.M.; Cruz, C.O. Green Roof and Green Wall Benefits and Costs: A Review of the Quantitative Evidence. Renew. Sustain. Energy Rev. 2021, 135, 110111. [CrossRef]

2. Nations Goal 11: Make Cities Inclusive, Safe, Resilient. Available online: https://scholar.google.com/scholar_lookup?title= Goal\%2011\%3A\%20make\%20cities\%20inclusive \%2C\%20safe \%2C\%20resilient \%20and\%20sustainable\&publication_year=2018 \&author=U.\%20Nations (accessed on 24 March 2021).

3. Nematzadeh, M.; Shahmansouri, A.A.; Fakoor, M. Post-Fire Compressive Strength of Recycled PET Aggregate Concrete Reinforced with Steel Fibers: Optimization and Prediction via RSM and GEP. Constr. Build. Mater. 2020, 252, 119057. [CrossRef]

4. Shahmansouri, A.A.; Akbarzadeh Bengar, H.; AzariJafari, H. Life Cycle Assessment of Eco-Friendly Concrete Mixtures Incorporating Natural Zeolite in Sulfate-Aggressive Environment. Constr. Build. Mater. 2021, 268, 121136. [CrossRef]

5. AzariJafari, H.; Gregory, J.; Kirchain, R. Potential Contribution of Deflection-Induced Fuel Consumption to U.S. Greenhouse Gas Emissions. Transp. Res. Rec. 2020, 2674, 931-937. [CrossRef]

6. Carter, T.; Jackson, C.R. Vegetated Roofs for Stormwater Management at Multiple Spatial Scales. Landsc. Urban Plan. 2007, 80, 84-94. [CrossRef]

7. Ebadati, M.; Ehyaei, M.A. Reduction of Energy Consumption in Residential Buildings with Green Roofs in Three Different Climates of Iran. Adv. Build. Energy Res. 2020, 14, 66-93. [CrossRef]

8. Kazemi, M.; Courard, L. Simulation of Humidity and Temperature Distribution in Green Roof with Pozzolana as Drainage Layer: Influence of Outdoor Seasonal Weather Conditions and Internal Ceiling Temperature. Sci. Technol. Built Environ. 2021, 27, 509-523. [CrossRef]

9. Almutairi, K.; Esfahani, E.M.; Mostafaeipour, A.; Issakhov, A.; Kaewpraek, C.; Techato, K. A Novel Policy to Optimize Energy Consumption for Dairy Product Warehouses: A Case Study. Sustainability 2021, 13, 2445. [CrossRef]

10. Kaewpraek, C.; Ali, L.; Rahman, M.A.; Shakeri, M.; Chowdhury, M.S.; Jamal, M.S.; Mia, M.S.; Pasupuleti, J.; Dong, L.K.; Techato, K. The Effect of Plants on the Energy Output of Green Roof Photovoltaic Systems in Tropical Climates. Sustainability 2021, 13, 4505. [CrossRef]

11. Nawaz, R.; McDonald, A.; Postoyko, S. Hydrological Performance of a Full-Scale Extensive Green Roof Located in a Temperate Climate. Ecol. Eng. 2015, 82, 66-80. [CrossRef]

12. Cascone, S.; Catania, F.; Gagliano, A.; Sciuto, G. A Comprehensive Study on Green Roof Performance for Retrofitting Existing Buildings. Build. Environ. 2018, 136, 227-239. [CrossRef]

13. Oberndorfer, E.; Lundholm, J.; Bass, B.; Coffman, R.R.; Doshi, H.; Dunnett, N.; Gaffin, S.; Köhler, M.; Liu, K.K.; Rowe, B. Green Roofs as Urban Ecosystems: Ecological Structures, Functions, and Services. BioScience 2007, 57, 823-833. [CrossRef]

14. Kazemi, M.; Courard, L. Modelling Thermal and Humidity Transfers within Green Roof Systems: Effect of Rubber Crumbs and Volcanic Gravel. Adv. Build. Energy Res. 2020, 1-26. [CrossRef]

15. Tabares-Velasco, P.C.; Zhao, M.; Peterson, N.; Srebric, J.; Berghage, R. Validation of Predictive Heat and Mass Transfer Green Roof Model with Extensive Green Roof Field Data. Ecol. Eng. 2012, 47, 165-173. [CrossRef]

16. Bollman, M.A.; DeSantis, G.E.; Waschmann, R.S.; Mayer, P.M. Effects of Shading and Composition on Green Roof Media Temperature and Moisture. J. Environ. Manag. 2021, 281, 111882. [CrossRef] [PubMed]

17. Lin, Y.J.; Lin, H.T.; Chou, C.Y. Physical Properties and Thermal Performance of Calcined Sludge as Planting Substrate in Green Roofs. Appl. Mech. Mater. 2011, 71-78, 3-11. [CrossRef]

18. Sun, T.; Bou-Zeid, E.; Wang, Z.-H.; Zerba, E.; Ni, G.-H. Hydrometeorological Determinants of Green Roof Performance via a Vertically-Resolved Model for Heat and Water Transport. Build. Environ. 2013, 60, 211-224. [CrossRef]

19. Kotsiris, G.; Androutsopoulos, A.; Polychroni, E.; Nektarios, P.A. Dynamic U-Value Estimation and Energy Simulation for Green Roofs. Energy Build. 2012, 45, 240-249. [CrossRef]

20. Côté, J.; Konrad, J.-M. A Generalized Thermal Conductivity Model for Soils and Construction Materials. Can. Geotech. J. 2011. [CrossRef]

21. Farouki, O.T. Thermal Properties of Soils; Cold Regions Research and Engineering Lab.: Hanover, NH, USA, 1981. 
22. Johansen, O. Thermal Conductivity of Soils; Cold Regions Research and Engineering Lab.: Hanover, NH, USA, 1977.

23. Lu, S.; Ren, T.; Gong, Y.; Horton, R. An Improved Model for Predicting Soil Thermal Conductivity from Water Content at Room Temperature. Soil Sci. Soc. Am. J. 2007, 71, 8-14. [CrossRef]

24. Berretta, C.; Poë, S.; Stovin, V. Moisture Content Behaviour in Extensive Green Roofs during Dry Periods: The Influence of Vegetation and Substrate Characteristics. J. Hydrol. 2014, 511, 374-386. [CrossRef]

25. He, Y.; Yu, H.; Dong, N.; Ye, H. Thermal and Energy Performance Assessment of Extensive Green Roof in Summer: A Case Study of a Lightweight Building in Shanghai. Energy Build. 2016, 127, 762-773. [CrossRef]

26. Pianella, A.; Clarke, R.E.; Williams, N.S.G.; Chen, Z.; Aye, L. Steady-State and Transient Thermal Measurements of Green Roof Substrates. Energy Build. 2016, 131, 123-131. [CrossRef]

27. Fabiani, C.; Coma, J.; Pisello, A.L.; Perez, G.; Cotana, F.; Cabeza, L.F. Thermo-Acoustic Performance of Green Roof Substrates in Dynamic Hygrothermal Conditions. Energy Build. 2018, 178, 140-153. [CrossRef]

28. Almeida, R.; Simões, N.; Tadeu, A.; Palha, P.; Almeida, J. Thermal Behaviour of a Green Roof Containing Insulation Cork Board. An Experimental Characterization Using a Bioclimatic Chamber. Build. Environ. 2019, 160, 106179. [CrossRef]

29. He, Y.; Yu, H.; Ozaki, A.; Dong, N. Thermal and Energy Performance of Green Roof and Cool Roof: A Comparison Study in Shanghai Area. J. Clean. Prod. 2020, 267, 122205. [CrossRef]

30. Wanielista, M.; Kelly, M.; Hardin, M. A Comparative Analysis of Greenroof Designs Including Depth of Media, Drainage Layer Materials, and Pollution Control Media; Florida Department of Environmental Protection: Tallahassee, FL, USA, 2008.

31. Palla, A.; Gnecco, I.; Lanza, L.G. Unsaturated 2D Modelling of Subsurface Water Flow in the Coarse-Grained Porous Matrix of a Green Roof. J. Hydrol. 2009, 379, 193-204. [CrossRef]

32. Kazemi, M.; Madandoust, R.; de Brito, J. Compressive Strength Assessment of Recycled Aggregate Concrete Using Schmidt Rebound Hammer and Core Testing. Constr. Build. Mater. 2019, 224, 630-638. [CrossRef]

33. Madandoust, R.; Kazemi, M.; Talebi, P.K.; de Brito, J. Effect of the Curing Type on the Mechanical Properties of Lightweight Concrete with Polypropylene and Steel Fibres. Constr. Build. Mater. 2019, 223, 1038-1052. [CrossRef]

34. Bengar, H.A.; Shahmansouri, A.A.; Sabet, N.A.Z.; Kabirifar, K.; Tam, V.W. Impact of Elevated Temperatures on the Structural Performance of Recycled Rubber Concrete: Experimental and Mathematical Modeling. Constr. Build. Mater. 2020, 255, 119374. [CrossRef]

35. Nematzadeh, M.; Dashti, J.; Ganjavi, B. Optimizing Compressive Behavior of Concrete Containing Fine Recycled Refractory Brick Aggregate Together with Calcium Aluminate Cement and Polyvinyl Alcohol Fibers Exposed to Acidic Environment. Constr. Build. Mater. 2018, 164, 837-849. [CrossRef]

36. Baradaran-Nasiri, A.; Nematzadeh, M. The Effect of Elevated Temperatures on the Mechanical Properties of Concrete with Fine Recycled Refractory Brick Aggregate and Aluminate Cement. Constr. Build. Mater. 2017, 147, 865-875. [CrossRef]

37. Mehrabi, P.; Shariati, M.; Kabirifar, K.; Jarrah, M.; Rasekh, H.; Trung, N.T.; Shariati, A.; Jahandari, S. Effect of Pumice Powder and Nano-Clay on the Strength and Permeability of Fiber-Reinforced Pervious Concrete Incorporating Recycled Concrete Aggregate. Constr. Build. Mater. 2021, 287, 122652. [CrossRef]

38. Yousefi Moghadam, S.; Ranjbar, M.M.; Madandoust, R.; Kazemi, M. Analytical Study on the Behavior of Corrosion-Damaged Reinforced Concrete Beams Strengthen with FRP. Rev. Romana De Mater. 2017, 47, 514-521.

39. Coma, J.; Pérez, G.; Castell, A.; Solé, C.; Cabeza, L.F. Green Roofs as Passive System for Energy Savings in Buildings during the Cooling Period: Use of Rubber Crumbs as Drainage Layer. Energy Effic. 2014, 7, 841-849. [CrossRef]

40. Coma, J.; Pérez, G.; Solé, C.; Castell, A.; Cabeza, L.F. Thermal Assessment of Extensive Green Roofs as Passive Tool for Energy Savings in Buildings. Renew. Energy 2016, 85, 1106-1115. [CrossRef]

41. Zhao, Z.; Courard, L.; Groslambert, S.; Jehin, T.; Léonard, A.; Jianzhuang, X. Use of Recycled Concrete Aggregates from Precast Block for the Production of New Building Blocks: An Industrial Scale Study. Resour. Conserv. Recycl. 2020, 157, 104786. [CrossRef]

42. Kazemi, M.; Hajforoush, M.; Talebi, P.K.; Daneshfar, M.; Shokrgozar, A.; Jahandari, S.; Saberian, M.; Li, J. In-Situ Strength Estimation of Polypropylene Fibre Reinforced Recycled Aggregate Concrete Using Schmidt Rebound Hammer and Point Load Test. J. Sustain. Cem.-Based Mater. 2020, 9, 289-306. [CrossRef]

43. Saberian, M.; Li, J.; Perera, S.T.; Anupiya, M.; Ren, G.; Roychand, R.; Tokhi, H. An Experimental Study on the Shear Behaviour of Recycled Concrete Aggregate Incorporating Recycled Tyre Waste. Constr. Build. Mater. 2020, 264, 120266. [CrossRef]

44. ISO 9869-1. Thermal Insulation, Building Elements, In-Situ Measurement of Thermal Resistance and Thermal Transmittance-Part 1: Heat Flow Meter Method; BSI: London, UK, 2014.

45. Coma, J.; de Gracia, A.; Chafer, M.; Perez, G.; Cabeza, L.F. Thermal Characterization of Different Substrates under Dried Conditions for Extensive Green Roofs. Energy Build. 2017, 144, 175-180. [CrossRef]

46. Ladani, H.J.; Park, J.-R.; Jang, Y.-S.; Shin, H.-S. Hydrological Performance Assessment for Green Roof with Various Substrate Depths and Compositions. KSCE J. Civ. Eng. 2019, 23, 1860-1871. [CrossRef]

47. Zhao, M.; Tabares-Velasco, P.C.; Srebric, J.; Komarneni, S.; Berghage, R. Effects of Plant and Substrate Selection on Thermal Performance of Green Roofs during the Summer. Build. Environ. 2014, 78, 199-211. [CrossRef]

48. ASTM D4611-16. Standard Test Method for Specific Heat of Rock and Soil; ASTM International: West Conshohocken, PA, USA, 2018.

49. ISO 16586 Soil Quality-Determination of Soil Water Content as a Volume Fraction on the Basis of Known Dry Bulk Density Gravimetric Method. Available online: https://www.iso.org/cms/render/live/en/sites/isoorg/contents/data/standard/03/2 3/32317.html (accessed on 27 October 2020). 
50. Künzel, H.M. Simultaneous Heat and Moisture Transport in Building Components. One-And Two-Dimensional Calculation Using Simple Parameters; IRB-Verlag: Stuttgart, Germany, 1995; p. 65.

51. Awulachew, S.B.; Lemperiere, P.; Tulu, T. Training Material on Agricultural Water Management; International Water Management Institute: Addis Ababa, Ethiopia; International Livestock Research Institute: Nairobi, Kenya; Adama University: Adama, Ethiopia, 2009; ISBN 978-92-9146-235-3.

52. Brouwer, C.; Goffeau, A.; Heibloem, M. Irrigation Water Management: Training Manual No. 1-Introduction to Irrigation; Food and Agriculture Organization of the United Nations: Rome, Italy, 1985; pp. 102-103.

53. EN 1925 Natural Stone Test Methods. Determination of Water Absorption Coefficient by Capillarity. Available online: https: //shop.bsigroup.com/ProductDetail?pid=000000000019973432 (accessed on 10 December 2020).

54. Vesuviano, G.; Stovin, V. A Generic Hydrological Model for a Green Roof Drainage Layer. Water Sci. Technol. 2013, 68, 769-775. [CrossRef]

55. EN 12620 Aggregates for Concrete. European Committee for Standardization. Available online: https://standards.iteh.ai/ catalog/standards/cen/aef412e6-36ce-49d3-afaa-5200d721ff84/en-12620-2013 (accessed on 19 January 2021).

56. ASTM D4716. Standard Test Method for Determining the (In-Plane) Flow Rate per Unit Width and Hydraulic Transmissivity of a Geosynthetic Using a Constant Head; ASTM International: West Conshohocken, PA, USA, 2013.

57. Dahanayake, K.C.; Chow, C.L. Comparing Reduction of Building Cooling Load through Green Roofs and Green Walls by EnergyPlus Simulations. In Building Simulation; Springer: Berlin/Heidelberg, Germany, 2018; Volume 11, pp. 421-434.

58. Poë, S.; Stovin, V.; Berretta, C. Parameters Influencing the Regeneration of a Green Roof's Retention Capacity via Evapotranspiration. J. Hydrol. 2015, 523, 356-367. [CrossRef]

59. Desogus, G.; Mura, S.; Ricciu, R. Comparing Different Approaches to in Situ Measurement of Building Components Thermal Resistance. Energy Build. 2011, 43, 2613-2620. [CrossRef]

60. Rodler, A.; Guernouti, S.; Musy, M. Bayesian Inference Method for in Situ Thermal Conductivity and Heat Capacity Identification: Comparison to ISO Standard. Constr. Build. Mater. 2019, 196, 574-593. [CrossRef]

61. Sailor, D.J.; Hagos, M. An Updated and Expanded Set of Thermal Property Data for Green Roof Growing Media. Energy Build. 2011, 43, 2298-2303. [CrossRef]

62. Cosenza, P.; Guérin, R.; Tabbagh, A. Relationship between Thermal Conductivity and Water Content of Soils Using Numerical Modelling. Eur. J. Soil Sci. 2003, 54, 581-588. [CrossRef]

63. Sepaskhah, A.R.; Boersma, L. Thermal Conductivity of Soils as a Function of Temperature and Water Content. Soil Sci. Soc. Am. J. 1979, 43, 439-444. [CrossRef]

64. Narsilio, G.A.; Kress, J.; Yun, T.S. Characterisation of Conduction Phenomena in Soils at the Particle-Scale: Finite Element Analyses in Conjunction with Synthetic 3D Imaging. Comput. Geotech. 2010, 37, 828-836. [CrossRef]

65. Woodside, W.; Messmer, J.H. Thermal Conductivity of Porous Media. I. Unconsolidated Sands. J. Appl. Phys. 1961, 32, 1688-1699. [CrossRef]

66. Yun, T.S.; Santamarina, J.C. Fundamental Study of Thermal Conduction in Dry Soils. Granul. Matter 2008, 10, 197-207. [CrossRef]

67. Toghroli, A.; Mehrabi, P.; Shariati, M.; Trung, N.T.; Jahandari, S.; Rasekh, H. Evaluating the Use of Recycled Concrete Aggregate and Pozzolanic Additives in Fiber-Reinforced Pervious Concrete with Industrial and Recycled Fibers. Constr. Build. Mater. 2020, 252, 118997. [CrossRef]

68. La Roche, P.; Berardi, U. Comfort and Energy Savings with Active Green Roofs. Energy Build. 2014, 82, 492-504. [CrossRef] 